Dialectologia. Special issue, 8 (2019), 29-33.

ISSN: 2013-2247

Received 18 March 2019.

Accepted 30 May 2019.

\title{
BASIC THOUGHTS ON GEOLINGUISTICS: A RESPONSE \\ TO THE PAPERS BY MOTOEI SAWAKI AND CHITSUKO FUKUSHIMA
}

\author{
Takuichiro ONISHI \\ National Institute for Japanese Language and Linguistics * \\ takonish@ninjal.ac.jp
}

\begin{abstract}
Though the field of Japanese geolinguistics was initially focused on finding scientific methods of mapping data, such as a location-numbering system, the field remains a part of humanities. The humanistic aspects of the Japanese location-numbering system should be reaffirmed and given a place of central importance in the study of geolinguistics.
\end{abstract}

Keywords

location-numbering system, humanities and geolinguistics, representativeness

REFLEXIONES BÁSICAS SOBRE GEOLINGÜÍSTICA. UNA RESPUESTA A LOS ARTÍCULOS DE MOTOEI SAWAKI Y CHITSUKO FUKUSHIMA

\section{Resumen}

Aunque el ámbito de la geolingüística japonesa se centró inicialmente en encontrar métodos científicos para la cartografía de datos, como un sistema de numeración de localizaciones, este ámbito sigue siendo parte de las humanidades. Los aspectos humanísticos del sistema japonés de numeración de localizaciones deben reafirmarse y otorgarles un lugar de importancia central en los estudios geolingüísticos.

\footnotetext{
* National Institute for Japanese Language and Linguistics, 10-2 Midori-cho, Tachikawa City, Tokyo, 190-8561 Japan.
} 


\section{Palabras clave}

sistema de numeración de localizaciones, humanidades y geolingüística, representatividad

\section{Introduction}

This is a response to the papers by Professors Motoei Sawaki and Chitsuko Fukushima. I will discuss the basic principles of geolinguistics here, focusing on the relationship between the location numbering systems and the humanities.

\section{The location-numbering system}

First, I will comment on the location-numbering system described in Professor Sawaki's paper. The system was used for the making of the LAJ (Linguistic Atlas of Japan) and the GAJ (Grammar Atlas of Japanese Dialects). I adopted GIS (geographical information systems) to analyze dialectal distributions fifteen years ago. The original location-numbering system was useful since GIS requires longitude and latitude and it is possible to calculate them from location numbers used in the location-numbering system.

However, there was just one problem. In the location-numbering system, the location number counts from the left to the right and also from the top to the bottom. The procedure is the same to obtain longitude in the Eastern Hemisphere (from the left to the right); however, it is the opposite in the case of latitude because it counts from the south to the north in the Northern Hemisphere, with the equator at zero degrees and the North Pole at 90 degrees. Therefore, it is necessary to add a formula to reverse the direction in order to obtain latitude.

Still, adopting the numbering system based on the maps of GSI (Geospatial Information Authority of Japan) was an excellent way. We could easily convert the data of the LAJ and the GAJ to those for the GIS analysis.

We conducted fieldwork in FPJD (Field Research Project to Analyze the Formation Process of Japanese Dialects: a project of National Institute for Japanese 
Language and Linguistics) between 2010 and 2015 with the goal of analyzing the formation process of Japanese dialects (sponsored by the National Institute of Japanese Language and Linguistics), as Professor Fukushima mentioned. I had decided not to adopt the location-numbering system but to use longitude and latitude. During our fieldwork, each location of dialectal distributions was treated as a point defined by longitude and latitude. I decided to use GIS based on a simple theory that I will mention in section 4 .

\section{Humanity in geolinguistics}

Professor Fukushima referred to "humanity" in geolinguistics. Sibata (1969) explained that there were eight keys for interpreting dialectal distribution. Two principles (adjacent distributions and surrounding distributions) are among them. Humanity is an important feature of the other keys, especially the fifth one, "the distributions of things and affairs expressed by words."

Sawaki (1979) wrote that "museological" knowledge (knowledge like that stored in museums) was required for this field. Dr. Mase was a participant in the Itoigawa research, the first scientific research on dialectal distributions, as Professor Fukushima mentioned (Mase 1992). He had studied theme-linking dialectology and folklore. Regretfully, Dr. Mase has passed away, and research in this area has stopped. This topic must continue to be explored in interdisciplinary research.

When I presented a geolinguistics paper about twenty years ago, Dr. Sibata commented that my logic was good but that I needed to incorporate more of the humanities into my work. I replied that the arguments I made regarding changes in languages over time and the factors influencing this process reflected the humanities, but I later realized that I had not answered Dr. Sibata's criticism directly. 


\section{Representativeness in geolinguistics}

When we make the study of dialect (dialectology) more scientific, the study sometimes becomes less humanistic. This tendency is not limited to dialectology but is common in many fields in the humanities. It may sound odd to some, but the adoption of a location-numbering system and the switch to the use of longitude and latitude have both humanistic and scientific implications in this field.

Japanese dialectology imported the Dutch method of mapping dialects with symbols. Symbol maps clearly show the dialect(s) of each place on a map. For example, multiple answers can be expressed easily; however, it was difficult in the case of choropleth maps used in the first Japanese dialectal atlases at the beginning of the twentieth century (Language Research Commission 1905, 1906).

Regardless of the method used to map dialects, it is necessary to verify that the number of places coded using the location-numbering system is equal to the number of informants. The data collected during fieldwork must represent the dialect of each hamlet, village, and town regardless of how it is mapped. The surveys of Nashinoki in the Itoigawa research (Sibata 1969: 72, 92-94, 99-100, 112) and Kochi by the NLRI (National Language Research Institute of Japan, which is now known as the National Institute of Japanese Language and Linguistics, or NINJAL) after the LAJ was published (Kato 1985) were done with the purpose of verifying the representativeness of the data.

Changing the location-numbering system of our work seems a mere technicality; however, we must make sure that the maps we produce are a faithful representation of the data. To achieve this, we must go back to the basics.

\section{References}

KATO, Masanobu (1985) "Hichosasha-no ninzu, joken shitsumonhoho-ni yoru sa: Kochishiniokeru chosa-kara" ["The differences between informants' methods and questionnaires: research in Kochi"], NLRI (eds.), Hogen-no Shoso: Nihon Gengochizu 
Dialectologia. Special issue, 8 (2019), 29-33.

ISSN: 2013-2247

Kenshochosa Hokoku [Various Phases of Dialects: Reports from Verifying Research of LAJ], Tokyo: Sanseido, 9-47.

Language Research Commission (Kokugo Chôsa linkai) (eds.) (1905) On'in bunpuzu [Phonetic dialect atlas], Tokyo: Nihonshoseki.

Language ReSeARCh Commission (Kokugo Chôsa linkai) (eds.) (1906) Kogoho bunpuzu [Grammatical dialect atlas], Tokyo: Kokuiteikyokasho-kyodohanbaijo.

MASE, Yoshio (1992) Gengochirigakuteki Kenkyu [Geolinguistic Study], Tokyo: Ofusha.

SAWAKI, Motoei (1979) "Mono-to kotoba" ["Things and language"], in Tokugawa, Munemasa (eds.), Nihon-no Hogenchizu [Japanese Dialectal Maps], Tokyo: Chukoshinsho, 53-97.

SIBATA, Takesi (1969) Gengochirigaku-no Hoho [Methodology of geolinguistics], Tokyo: Chikumashobo. 